\title{
MARÍA ZAMBRANO: LA VOCACIÓN COMO MEDIACIÓN Mariana Bernárdez*
}

RESUMEN: Mediante breves trazos de su vida y obra, se muestra cómo entendía María Zambrano la labor del intelectual: una vocación destinada a entender la realidad y a transformarla por medio de su inseparable labor de maestro de la sociedad.

PALABRAS ClaVE: María Zambrano, educación, vocación, labor intelectual.
ABSTRACT: Through snippets of her life and work, we acquire an understanding of Maria Zambrano's perception of intellectual work: a calling to understand reality and transform it through teaching.

KEYWORDS: María Zambrano, education, calling, intellectual work.
RECEPCIÓN: 27 de junio de 2008.

ACEPTACIÓN: 26 de agosto de 2008.
* Ensayista. 


\title{
MARÍA ZAMBRANO: LA VOCACIÓN COMO MEDIACIÓN
}

\author{
Termino pidiéndote. Pidiéndote que enciendas tres \\ velas ante la Virgen cuando por alli vayas. Una por \\ Araceli-se acaba de cumplir iya! el cuarto aniversa- \\ rio-, otra por el bien de España, y la otra por los que \\ sufren de soledad. Por todos los solos. ${ }^{1}$
}

$\mathrm{Di}$ icen que la historia la escriben los vencedores, pero ese no fue el caso de la España Peregrina, aquella España que a pesar de haber perdido la guerra ganó la historia. ${ }^{2}$ Resultado del éxodo fue la llegada a nuestro país de intelectuales que supieron vivir a la altura de sus circunstancias; se incorporaron a las aulas, a las instituciones y a la vida diaria, con la certeza de poder enraizarse y dejar atrás una guerra, que entre otras muchas cosas, fue la antesala del horror que se desplegaría durante la Segunda guerra mundial. No obstante, la preo-

${ }^{1}$ María Zambrano, "Cartas a Alfonso Roig Izquierdo, La Piece, 29-2-76”, en Testimoni del exili: Alfonso Roig i els seus amics, 1988, Valencia, Diputación de Valencia, (libro-catálogo), p. 49.

${ }^{2}$ Cfr., Javier Cercas, Soldados de Salamina, 2001, España, Tusquets. cupación de tratar de comprender este sino de perversión, esta embriaguez provocada por la falsedad de un delirio proveniente de la creencia de que el hombre puede ser dueño de un semejante, esta mueca de sí mismo que le llevó a arrojarse, sin más, al abismo, permaneció en ellos y fue herencia ineludible para las generaciones subsecuentes.

Entre las figuras del exilio español que fueron reconvenidas mediante la Casa de España, hoy El Colegio de México, institución creada por deseo expreso del General Lázaro Cárdenas, encontramos a María Zambrano, y me es difícil centrar mi atención en un planteamiento específico, porque al hablar de Zambrano se quiere oír sobre la Razón Poética, el Sueño Creador, la Metáfora del 
Corazón... y yo, por el contrario, trataré de abordar algunas ideas sobre el papel mediador del intelectual y del maestro. ¿Por qué? Confieso que a la distancia más que respuestas, lo que me restan son inquietudes, intuiciones que no sé si alcancen el albor de la pregunta, atisbos que me permito compartir con el temblor propio de quien se sabe cierta al equívoco.

¿Qué lucidez había en Zambrano como para que alcanzara estudios universitarios y se distinguiera entre pensadores tales como García Morente, Julián Besteiro, Xavier Zubiri; como para vivir muy de cerca el acontecer histórico político de esos años que llevaron a la proclamación de la Segunda República, desistiendo de un escaño político y sumándose a las Misiones Pedagógicas, donde conoció a Cernuda, Rafael Dieste, Ramón Gaya, Maruja Mallo, Alberti, Nadal, Miguel Hernández, Altolaguirre, Serrano Plaja, por mencionar a algunos?, ¿qué lucidez para abreviar su estancia en Chile $^{3}$ tras el asesinato de García Lorca y publicar en homenaje una breve antología poética? "Decidimos regresar a España, en el momento en que era más evidente que nunca la derrota de la causa en la que creíamos. ¿Y por qué vuelven ustedes a España si saben muy bien que su causa está perdida? Pues por

${ }^{3}$ La Segunda República Española nombra a su marido Alfonso Rodríguez Aldave segundo secretario de la Embajada de España en Chile. esto, por esto mismo." " En entrevista con Adolfo Castañón años después comenta: “¿La guerra? -empezó a decir con voz distraída. La guerra civil no la perdimos una vez sola; la perdimos para siempre. Cuando me di cuenta de ese hecho decidí volver a mi país." ${ }^{5}$

María tenía temple porque sabía escuchar con el corazón, y había que tener ambos para vivir en guerra, para ser miembro del Consejo de Propaganda y del Consejo Nacional de la Infancia Evacuada, para no perderse en la sinrazón; para escribir y fundar la revista Hora de España. Al caer Barcelona salió dos horas antes de que se cerrara la frontera, por los Pirineos hacia Francia, junto con Antonio Machado y su madre y tantos otros. Comenzaba el periplo del exilio y el de la persecución; cito a Agustín Andreu:

Sospechosa de comunista y de intelectual superpeligrosa, se pasó la vida atendida por las policías de EE.UU. en Puerto Rico y en Cuba, de las policías italianas y española en Roma y Ginebra... Y hay que recordar las visitas de la Gestapo en París a [su hermana] Araceli para sonsacarle por métodos de todo tipo los nombres de amigos de su mari-

${ }^{4}$ María Zambrano, Poesía y filosofia, 1987, México, FCE, colec. Sombra del Origen, p. 9.

${ }^{5}$ Adolfo Castañón, "María Zambrano: sueño o verdad", en La gruta tiene dos entradas, 1994, México, Vuelta, p. 205. 
do, organizador de la Resistencia cuando la ocupación alemana en París. Su marido, dado el silencio pertinaz de Araceli, fue entregado al gobierno del General Franco y fusilado. María se sentía sitiada por la policía demiúrgica [...] sus amigos en tiempos difíciles, éramos agraciados con atenciones parecidas. ${ }^{6}$

Sigue un largo viaje: París, Nueva York, La Habana y finalmente llega a México. Sobre esta época es de interés la correspondencia con Alfonso Reyes de reciente publicación bajo el título Días de exilio, ${ }^{7}$ donde se muestran algunas aristas de este complejísimo momento histórico; María obtiene gracias a la Casa de España un puesto en la Universidad San Nicolás de Hidalgo en Morelia, Michoacán de la que dice: "Morelia cuyo camino no busqué, sino que él mismo me llevó hacia ella, igual que a tantos otros españoles, recién llegados del destierro."

${ }^{6}$ Agustín Andreu, "Nota 81”, en Maria Zambrano. Cartas de La Pièce. (Correspondencia con Agustín Andreu), 2002, España, Edición de Agustín Andreu, Pre-Textos y Universidad Politécnica de Valencia, p. 79.

${ }^{7}$ Días de exilio. Correspondencia entre María Zambrano y Alfonso Reyes 1939-1959, 2006, El Colegio de México y Taurus de Santillana Ediciones Generales, México, compilación, estudio preliminar y notas Alberto Enríquez Perea. Véase también la entrevista con el autor http://www. ensayistas.org/filosofos/spain/zambrano/entrevistas/reyes-zambrano.htm, donde se ahonda sobre esta visión.

${ }^{8}$ Vicente Guarner, "María Zambrano, 19041991. Morir al alba, con esa luz que siempre
Imparte una variedad de cursos sobre psicología, sociología e introducción a la filosofía, y desarrolla una serie de conferencias que resultarán en su primer libro 'americano', me refiero a Pensamiento y poesía en la vida española. Las conferencias fueron acordadas con Reyes y las dictó como miembro de la Casa de España en un salón de la Sociedad de Geografía e Historia, ubicada frente a San Ildefonso, en pleno barrio universitario de la ciudad de México, que era sin duda el eje cultural y político del país, lo cual destaco pues las fechas en que fueron impartidas, a mediados de junio, coincide con la llegada del Sinaia al Puerto de Veracruz. Bajo este contexto las pláticas fueron el corolario de una visión que rescataría las preocupaciones del intelectual frente a España y que darían fe del correr de los tiempos; así, María dio testimonio de la generosidad de México y a la par asumió, a nombre del exilio, el legado histórico que habría de perdurar a pesar de la catástrofe de una Europa pronta a destruirse.

Otro libro producto de su estancia en Morelia fue Filosofía y Poesía, sirguilla hacia la razón poética, una razón que manifiesta una pasión por el logos-nous poético, y que avanza sobre la razón vital e histórica pro-

precede al sol en su silencio", Excélsior, 17 de febrero de 1991, s/p. 
puesta por quien fue su Maestro, Don José Ortega y Gasset, lo cual era y fue en su momento escandaloso, pero no hay que olvidar que el verdadero conocimiento, aquél cuyo centro mana de un caudal amoroso, siempre escandaliza.

María abandona México a principios de 1940, invitada por el Instituto de Altos Estudios e Investigaciones Científicas de la Universidad de La Habana, para dictar una serie de conferencias sobre Ortega y Gasset en el Ateneo; reside en Cuba por 13 años más y se integra al grupo de escritores encabezado por José Lezama Lima con la revista Orígenes. ${ }^{9}$

Los siguientes años serán decisivos en el pensamiento de Zambrano; al tener como marco de referencia la Segunda guerra mundial, es natural e incluso obligado que reflexione en voz alta y escriba sobre Europa y el fenómeno de la violencia, y que considere cuál habrá de ser la posición del intelectual frente a tales

${ }^{9}$ María, Zambrano, "Breve testimonio de un encuentro inacabable", en María Zambrano, Antología, selección de textos, Anthropos. Revista de Documentación Científica de la Cultura. Suplementos \#2, No. 70/71 (marzo-abril 1987). p. 43. "Los diez poetas del grupo Orígenes de Lezama y su revista, en cuya fundación yo tuve parte anónima y decisiva, me fueron presentados. Me pidieron ayuda para que su labor tuviera el reconocimiento que merecía. Les prometí que así lo haría en mis colaboraciones en revistas de prestigio de América y de Europa. Uno de los diez, Cintio Vitier, me respondió 'No, María, nosotros somos de aquí, queremos ser reconocidos aquí'. Le di entonces mi primer artículo para Orígenes." hechos. Entre 1940-1943 publicará en la revista Sur, dirigida por Victoria Ocampo, tres artículos: "La agonía de Europa", "La violencia europea" y "La esperanza europea", que conformarán el libro La agonía de Europa publicado en 1945 y al que se le añadirá otro ensayo más "La destrucción de las formas". ¿De dónde la violencia? Retomo ciertas ideas del libro señalado:

Lo que se percibe en el estallido del corazón europeo es la violencia que se forma desde su raíz y su origen se revela [...] en lo que durante siglos ha adorado cada vez más furiosamente, en su culto absorbente y fanático que siendo un culto dirigido a la verdad, puede parecer, algunas veces, una idolatría, al caer el hombre europeo en el frenesí de glorificarse por la creación [...] de ser a imagen y semejanza de un Dios activo que de la nada saca el mundo, la espléndida realidad que es la mayor acción de todas, la absoluta acción [...] entonces, es en la idea que el hombre se ha hecho de sí mismo como una criatura que puede crear su mundo, donde radica la mayor violencia y en ello se usaron todas las razones [...] hasta que la razón misma se consumió y se hizo de nuevo, y por la mano del hombre, nada. ${ }^{10}$

${ }^{10}$ María Zambrano, La agonía de Europa, 1988, España, Mondadori, colec. Ensayo-Bolsillo, p. $31,33,43$. 
Estas reflexiones tendrán mucho que ver con un suceso significativo; en el ámbito internacional, me refiero a la Conferencia sobre Cooperación Intelectual que se organiza en La Habana, a finales de noviembre de 1941, bajo el tema de "América ante la crisis mundial". ${ }^{11}$ Asisten Jules Romains, Ribeiro de Couto, Hans Kelsen, William Berreen, Herni Bonnet, Thomas Mann, Paul Rivet, Max Henríquez Ureña, Antonio Castro Leal, Samuel Ramos, Alfonso Reyes que fungirá como Presidente de la plática y María Zambrano, entre otros. No me detendré en la trama que dio lugar a este encuentro, ni en la polémica que se sostuvo, sino en la pregunta hecha por Herminio Portell Vilá: “¿Cuál sería la actitud de los intelectuales en América en cuanto a la tolerancia e intolerancia? ¿Seremos intolerantes con aquellos que lo son o para defender la democracia recibiremos en nuestros países a todos para que disfruten de los derechos que ellos nos niegan y así puedan a su antojo destruir nuestros sistemas?"12 Pregunta cuya vigencia

${ }^{11}$ La Comisión Cubana de Cooperación Intelectual decide celebrar con motivo de la Segunda Conferencia Americana de Comisiones Nacionales de Cooperación Intelectual (1941) estas pláticas. La información expuesta es obtenida de Plática de la Habana. América ante la crisis mundial, 1943, La Habana, Cuba, Comisión Cubana de Cooperación Intelectual.

${ }^{12}$ Días de exilio. Correspondencia entre María Zambrano y Alfonso Reyes 1939-1959, op. cit., p. 120. después de 75 años es atormentadora; los hombres no sólo no hemos logrado superar el lenguaje de la violencia y la intolerancia, sino que nos regodeamos en su interior.

Zambrano enuncia lo que será reflejo de una heredad proveniente de los que habían caído y de aquellos que sin entender por qué hubieron de mantenerse la vida entera de pie para asumir el reclamo que implicó el fracaso de la razón y que dio lugar a la violencia, al aniquilamiento de las formas que median en todo modo de convivencia y de trato, y a la pérdida del sentido de la esperanza: el hombre no sabe qué esperar y extraído de la cadencia temporal, sin la posibilidad de atisbar un horizonte, se adentra en el paroxismo del terror:

Nada hay 'en el mundo que esté más en crisis que la función del intelectual' y la 'responsabilidad de la inteligencia' [...] ¿Pero es de veras que la responsabilidad atañe al intelectual? ¿No es algo que tenemos en función de ser, algo más hondo y previo que los intelectuales, es decir, personas? ¿ese maravilloso compuesto de libertad, de inteligencia y de dignidad? ${ }^{13}$

El intelectual es una persona que ha desarrollado la facultad de

${ }^{13}$ María Zambrano, Plática de La Habana: América ante la crisis mundial, op. cit., p. 105-6, 107, 225-6 y 229. 
la inteligencia y por ello le incumbe el problema de su responsabilidad que es "el de la lealtad para con ella misma y mucho más cuando vemos hoy que la inteligencia, después de 24 siglos en que Platón pidiera utópicamente el poder para ella, sigue sin más armas que ella misma. Sigue sola [...] terriblemente sola." ${ }^{14}$ Y prosigue preguntándose en qué consiste este ser del intelectual como un ser de inteligencia, ¿qué lo distingue su universalidad y su impasibilidad?:

[Mas] la impasibilidad de la inteligencia tiene una condición contradictoria entre otras, pero no en ella: que es amorosa [...] Existe un 'amor intelectual', un amor propio de la inteligencia [...] En efecto, la inteligencia, es por esencia, mediadora [...] En palabras de un poeta europeo, español, [...] es 'el ángel entre Dios y el hombre'. Es decir, el mediador por esencia, un mensajero de la verdad universal. Pero, ¿hacia dónde? Hacia la natural obscuridad de la vida [...] Porque toda la vida es obscura, y mucho más en sus entrañas. ${ }^{15}$

El intelectual en su labor de mediación rompe con el desamparo propio de quien por cobijo ha tenido no la benevolencia de la muerte sino la crueldad como horizonte de vida, al desplegar el futuro como posibili-

${ }^{14}$ Ibid., p. 106.

${ }^{15}$ Ibid., p. 107. dad imanta la esperanza y la voluntad de construir, que toda construcción es a final de cuentas una creación, pero este responder se sustenta en la comprensión de que:

No se puede ser intelectual, ni ninguna otra cosa cualquiera, sin ser previamente persona humana, es decir, ser que está en profunda convivencia con todo lo que le rodea, y que no puede, en modo alguno, desprenderse de los acontecimientos que atañen a los hombres y a él personalmente. ${ }^{16}$

La persona se integra a partir de su relación con los otros y es en ella donde radica la certeza de que a pesar de la crisis existe más allá de la violencia un camino de conversión, un vislumbrar lo que pesa adentro, como bien escribe Zambrano, la carga vacía de un corazón sin marcha. ${ }^{17}$

Se es un intelectual en tanto que se es persona, concepto al que presta atención en La confesión como género literario (1943), La agonía de

\footnotetext{
${ }^{16}$ María Zambrano, Plática de La Habana, op. cit., p. 226 y también Días de exilio, op. cit., p. 127-8. Más adelante, p. 228, dice que ha llevado su vida: "de refugiada política al último extremo, y que sintiendo tras de mí a mis compañeros muertos, y a los que están en la cárcel, y a los que no comen, y sintiendo esa tragedia de la que soy uno de los millones de protagonistas, he pedido un poco de serenidad, de inteligencia y de cordura. Nada más."

${ }^{17}$ María Zambrano, Delirio del in-crédulo, enero de 1950, Roma, Hotel D’Inglaterra, poema dado por la Fundación Zambrano.
} 
Europa (1945), y años más tarde en Persona y democracia (1958). Ser persona, implica para nuestra autora la expresión más alta que alcanza el hombre porque:

Conocerse a sí mismo o a otro, conocer a una persona, es saber qué espera de verdad. El hombre es una criatura impar, cuyo ser verdadero está fiado al futuro, en vía de hacerse. Existe un trabajo aún más inexorable que el de 'ganarse el pan'. Es el trabajo de ganarse el ser, a través de la vida. ${ }^{18}$

Trascender es hacerse en la realidad, que es el lugar de encuentro con los otros y lo otro, confirmándose que el acto de hacerse es un acto de religación por el que se acepta la vocación que habita en nuestro interior; ¿qué entender por vocación?, sino aquello que:

Revela de modo privilegiado la esencia trascendente del hombre y su realización concreta. [...] Toda vocación es en esencia mediadora [...] entre las fuerzas y modalidades que constituyen al individuo, entre los planos del ser y de la realidad, de la vida y la razón. [...y] entre el individuo y la sociedad, pues que toda vocación al acabar en una

${ }^{18}$ María Zambrano, "Tres apuntes: Qué es la adolescencia. De la necesidad y de la esperanza. Areté, virtus, eficacia", en Educación, n ${ }^{\circ} 36$, marzo, 1973, San Juan de Puerto Rico, p. 73-4. ofrenda es por esencia de naturaleza social. ${ }^{19}$

¿Desde dónde el intelectual habrá de mediar? ¿Desde la cátedra, el púlpito, el periódico? ¿Habrá de apropiarse del ejercicio propio del maestro?, ¿forzosamente un intelectual es un maestro?

Se puede y aun es necesario que el magisterio se ejerza de muchas maneras en una sociedad $[. .$.$] hay$ funciones lindantes con la suya [...] no sucede por simple azar que algunos regímenes políticos, algunos hombres de Estado choquen con el magisterio establecido y actuante. $Y$ que el cuerpo escolar en su integridad se mueva dentro de dimensiones que podemos llamar políticas. ${ }^{20}$

El intelectual y el maestro tendrán en común la vocación y el ser personas; habrá momentos donde un intelectual adquiera las funciones de un maestro y viceversa. La lección de Zambrano es clara y contundente, la afirmación de la inteligencia es el papel irrevocable que habrán de interpretar estas dos figuras frente al señorío de la violencia, cuyos privilegios se desmoronan ante la capacidad de la razón para razonar, ¿pero si la razón está en crisis, entonces cómo pensar?

${ }^{19}$ María Zambrano, La vocación del maestro, 1965, Italia, Ágora, p. 129.

${ }^{20}$ Ibid., p. 131. 
La cuestión es que lo que se halla en crisis no es la razón sino las formas de su manifestarse, lo cual es evidente en el agotamiento de sus esquemas. Tanto el intelectual como el maestro han sabido en su momento vislumbrar esta queja y sólo mediante un saber compasivo, que rebasa la argumentación de un discurso probatorio, es posible crear nuevas formas de trato; un saber que se ofrece en prenda para vencer el cerco de la mudez que sobreviene ante la incordura, saber de experiencia que es enseñado por medio del gesto, una forma de pensamiento de significación profunda y actuante que penetra en el corazón y donde el pensamiento es sólo dimensión de algo más complejo: una situación vital de la que se quiere hacer salir a alguien. ¿De qué otra forma puede el intelectual y el maestro enseñar a ser persona a un hombre que ha perdido para sí el sentir de su propio centro, al que el estallido de su corazón lo ha sumergido en las más profundas tinieblas?

Podría medirse quizá la autenticidad de un maestro por ese instante de silencio que precede a su palabra, por ese tenerse presente, por esa presentación de su persona antes de comenzar a darla de modo activo. $\mathrm{Y}$ aun por el imperceptible temblor que le sacude. [...] una lección ha de darse en estado naciente. Se trata, en la transmisión oral del conoci- miento de un doble despertar, de una confluencia del saber y del no saber todavía. Y esto doblemente, pues que [...] el alumno comienza a serlo cuando se le revela la pregunta que lleva dentro agazapada. La pregunta que es, al ser formulada, el inicio del despertar de la madurez, la expresión misma de la libertad. [...] El alumno se yergue. $Y$ es ese segundo instante cuando el maestro con su quietud, ha de entregarle lo que parece imposible, ha de trasmitirle, antes que un saber, un tiempo; un espacio de tiempo, un camino de tiempo. $^{21}$

El maestro marca una pauta, un ritmo, una perspectiva: la realidad de otro modo de vida, de una verdad tan de adentro que a veces es inadvertida, pero que es "la que la vida necesita, $[\ldots]$ la que es capaz de renacer tantas veces como sea necesitada." 22 Se trata de una verdad que transforma la vida porque se arraiga al transcurrir temporal, acción que arranca al corazón del pasmo en el que ha estado sumergido; así, a pesar de haber estallado, de haber cruzado los derroteros de la ira, de haber engendrado la violencia, y, aterido, haber detenido su marcha, el latido se acompasa poco a poco

${ }^{21}$ Ibid., p. 137-9.

${ }^{22}$ María Zambrano, "La Guía, forma de pensamiento", en Hacia un saber sobre el alma, 1989, Madrid, España, Alianza, Colección Alianza Tres, p. 71. 
y transparenta su interior; entonces se recuerda centro y el razonar que sale de su pálpito respeta el sentido originario, aquél que encuentra: "el sentido múltiple y al mismo tiempo único de la palabra, sus raíces ocultas que velan y desvelan un misterio profundo. ${ }^{.23}$ He aquí el legado de Zam- brano que demanda en prenda el ser capaces de responder a las exigencias de nuestro tiempo como intelectuales y como maestros, como creadores no sólo de una idea del hombre sino de la manifestación más alta del quehacer humano: la inteligencia amorosa que nos conforma como personas.

${ }^{23}$ J. F. Ortega, María Zambrano: su vida y su obra, 1992, Málaga, España, Cuadernos de Puerta Nueva, Serie de Arte y Pensamiento, Junta de Andalucía, Conserjería de Educación y Ciencia, Conserjería de Cultura y Medio Ambiente, Delegaciones Provinciales de Málaga y Unicaja, p. 49. 